\title{
PRICE DETERMINACY UNDER NON-RICARDIAN FISCAL STRATEGIES
}

oscar Arce

Documentos de Trabajo N. 0741

\section{BANCOUESPANA}


PRICE DETERMINACY UNDER NON-RICARDIAN FISCAL STRATEGIES 
PRICE DETERMINACY UNDER NON-RICARDIAN FISCAL

\section{STRATEGIES}

Óscar $\operatorname{Arce}^{(*)}$

BANCO DE ESPAÑA

(*) I wish to thank Javier Andrés, Charles Goodhart, Tim Kehoe, Juan F. Jimeno, David López-Salido, Albert Marcet, and participants at several seminars at the Banco de España and London School of Economics for their helpful comments on various versions of this work. I am particularly indebted to Nobuhiro Kiyotaki for his valuable advice and suggestions. An anonymous referee of the Banco de España working paper series provided very insightful suggestions. All errors are mine.

Disclaimer: The views expressed herein are those of the author and not necessarily those of the Banco de España or the Eurosystem.

Author's address: Research Department, Banco de España. Calle Alcalá, 48, 28014 Madrid, Spain. Phone: +34 91 338 6061. Fax: +34 91338 5678. e-mail: o.arce@bde.es. 
The Working Paper Series seeks to disseminate original research in economics and finance. All papers have been anonymously refereed. By publishing these papers, the Banco de España aims to contribute to economic analysis and, in particular, to knowledge of the Spanish economy and its international environment.

The opinions and analyses in the Working Paper Series are the responsibility of the authors and, therefore, do not necessarily coincide with those of the Banco de España or the Eurosystem.

The Banco de España disseminates its main reports and most of its publications via the INTERNET at the following website: http://www.bde.es.

Reproduction for educational and non-commercial purposes is permitted provided that the source is acknowledged.

\section{(C) BANCO DE ESPAÑA, Madrid, 2007}

ISSN: 0213-2710 (print)

ISSN: 1579-8666 (on line)

Depósito legal: M.56517-2007

Unidad de Publicaciones, Banco de España 


\section{Abstract}

This paper shows that there exist fiscal strategies that deliver equilibrium uniqueness in a monetary economy in which the central bank follows an interest rate peg. In contrast to the fiscal theory of the price level (FTPL), such strategies always satisfy a government intertemporal budget constraint. The government is able to rule out most prices using strategically its fiscal instruments, undercutting the private-market price whenever it is inconsistent with the fiscal targets. In the spirit of the FTPL, along the fiscal strategies of this paper the government does not follow a rule that mechanically links the fiscal surplus to the real value of its outstanding nominal debt. Like in the monetarist paradigm, the fiscal authority is forced to blink in face of an independent monetary policy, although in equilibrium the former achieves its own targets.

Keywords: Fiscal-monetary interactions; Fiscal Theory of the Price Level; interest rate peg; equilibrium (in)determinacy.

JEL classification: E31, E42, E61. 


\section{Introduction}

Sargent and Wallace (1981) explore a natural way in which fiscal and monetary policies are related by highlighting the role played by the government intertemporal budget constraint. A central message from their paper is that a certain degree of coordination between fiscal and monetary decisions is always required, regardless of the particular policy regime at work. Also, fiscal variables, such as taxes or public debt, can affect nominal variables like prices or the stock of money only if the central bank accommodates its policy to achieve a seigniorage target under a fiscal-dominance regime. Overall, in their economy the monetarist dictum applies: the price level is always a monetary phenomenon, in spite of the eventual fiscal roots of the observed monetary stance.

In recent times, some economists have challenged the above arguments concerning both the necessity of monetary and fiscal coordination and the monetary nature of the price level, developing the Fiscal Theory of the Price Level (FTPL). ${ }^{1}$ The cornerstone of this theory is the assumption that the government can commit to non-Ricardian rules that involve fiscal-monetary plans that need not to satisfy a government intertemporal budget constraint. This assumption delivers a number of results that contrast with the standard monetarist doctrine. Under a non-Ricardian plan, the monetarist dictum breaks down and the price level is fundamentally a fiscal phenomenon, with monetary aggregates playing a marginal role. Importantly, the FTPL contends that the classic nominal indeterminacy problem associated with a nominal interest rate peg vanishes under an appropriate non-Ricardian policy.

In this paper we show that there are fiscal strategies that determine a unique equilibrium price level under an interest rate peg and that satisfy the government intertemporal constraint under any circumstance. Thus, we depart from the class of non-Ricardian policies advocated by the FTPL. Yet, in the spirit of the FTPL, fiscal strategies that deliver equilibrium uniqueness in our theory require that the government does not follow a rule that mechanically links the total fiscal surplus to the real value of its outstanding nominal debt. In this sense, this paper aims at bridging the two paradigms at stake. On the one hand, we provide a foundation for fiscal determination of the price level based on non-Ricardian elements and, on the other, we do so in a way that is robust to main criticism against the FTPL, namely, the view that the government budget constraint is only an equilibrium condition. ${ }^{2}$

\footnotetext{
${ }^{1}$ Some of the seminal works on the FTPL include the following: Leeper (1991), Sims (1994), Woodford (1994, 1995) and Cochrane (2001). Other contributions supporting its theoretical foundations are contained in Woodford (1998, 2001), Sims (1999), Bassetto (2002), Cochrane (2005), Davig and Leeper (2006), and Daniel (2007). Kocherlakota and Phelan (1999), Christiano and Fitzgerald (2000), and Bassetto (2007) explain the basic arguments of the FTPL.

${ }^{2}$ See, for instance, the critical discussions of the FTPL by Cushing (1999), McCallum (2001), Buiter (2002) and Niepelt (2004).
} 
The basic argument works as follows. Like in the FTPL, we consider targets for government spending and taxes that are compatible with a unique equilibrium price level, say $\widetilde{P}$, as maturing government debt provides a nominal anchor for the economy. Key to our arguments is the idea that there are two potential sources of value for money (and, hence, for goods). First, money permits a household to carry out transactions with other households, as private consumption of goods is subject to a cash-in-advance constraint. Second, a household may also use money to obtain goods from the fiscal branch of the government, should the latter decide to give goods in exchange for money. When the transactions value of money (i.e. the inverse of the price level, $P$ ) falls below the one consistent with fiscal targets, that is $P>\widetilde{P}$, the real value of maturing government debt also falls below the target. Then, the government uses such unplanned extra resources to acquire money from the private sector setting a fiscal value of money above the transactions one, ${ }^{3}$ through an operation that essentially transforms money into a residual claim on the fiscal surplus. In so doing, the government rules out such price $P>\widetilde{P}$ as an equilibrium one. The non-Ricardian nature of this strategy lies on the fact that the commitment to offer a fiscal value above the transactions one is incompatible with the commitment to make the total fiscal surplus equal to the value of the government debt at all times.

We then construct an inverse argument to rule out any price $P<\widetilde{P}$. In face of such eventuality the fiscal branch of the government allows households to deliver goods in exchange for money at a fiscal value of goods above the transactions one. While such a disequilibrium situation persists, the real value of government debt obligations rises and the government is forced to run a fiscal surplus above the target, raising taxes as much as necessary to provide an advantageous fiscal value of goods.

The idea behind the fiscal equilibrium selection mechanism of this paper can be traced as back as Wallace (1981) and Obstfeld and Rogoff (1983). In these papers the central bank sets a constant path for the stock of money and besides the standard monetarist equilibrium there may exist other equilibria in which money becomes valueless. However, these latter equilibria can be ruled out by the government if it commits to back money by intrinsically useful objects. Our economy differs from the ones studied by these authors in an important dimension, namely that the central bank in this paper follows a rule that leaves the stock of money indeterminate. Such indeterminacy allows certain fiscal strategies, as the one outlined above, to operate as an equilibrium selection device. In turn, the government rules out some prices by managing its fiscal surpluses strategically, rather than by violating its budget constraint.

\footnotetext{
${ }^{3}$ We are borrowing the transactions and fiscal values terminology from Diamond and Rajan (2006).
} 
We develop our arguments in the context of a non-Walrasian monetary economy. This latter feature is motivated by Bassetto's (2002) criticism of the FTPL, who argues that the Walrasian framework is not the appropriate one to deal with a theory that critically depends on assumptions about the off-equilibrium dynamics of the economy. In particular, the price formation mechanism is explicitly modelled by means of a system of trading posts or "markets" at which goods and assets are traded pairwise. Such structure facilitates the lay out of the set of constraints that market participants face at each stage of the trade-consumption process.

Apart from other details of the modeling strategy, we depart from Bassetto's cash-less assumption and build up an economy in which money exists physically and is traded for goods (and goods for money). A key motivating idea in this paper is that the forces behind the equilibrium price determination of a non-fiat asset (like a non-defaultable bond) need not to coincide with those behind the determination of a fiat asset. In the above terminology, a bond only has a fiscal value while money may have a transactions value even if its fiscal value is zero.

In particular, we employ a version of the one-period monetary economy presented by Gale (2005), augmented with fiscal variables, in which a central bank lends money to the households and charges a positive interest rate on its loans. ${ }^{4}$ Such framework allows for a transparent description of the actions taken by the central bank and the fiscal authority, and of the constraints that an independent monetary policy poses on fiscal policy. An important assumption maintained in this paper is that the central bank never monetizes fiscal deficits. To our knowledge, no previous paper has attempted to analyze the interactions between independent fiscal and monetary authorities by fully specifying government strategies.

The paper is organized as follows. Section 2 contains the monetary model and presents the FTPL's arguments in a Walrasian setting and section 3 contains a description of the non-Walrasian economy. Section 4 develops the equilibrium uniqueness result under a non-Ricardian government strategy. Section 5 contains a detailed discussion of such result in the light of the some of the previous literature and briefly discusses some extensions. Section 6 concludes.

\section{Ricardian and non-Ricardian policies}

In this section we first provide the baseline monetary model employed throughout and then describe the FTPL arguments in that context.

\footnotetext{
${ }^{4}$ The one-period simplification has been used by both proponents and opponents of the FTPL, see e.g. Christiano and Fiztgerald (2000), Niepelt (2004), and some examples in Cochrane (2005). As shown in section 2, our one-period economy is valid to capture the main insights of both the traditional monetarist and the FTPL arguments.
} 
Consider an economy inhabited by a continuum of identical households of measure one, a central bank and a fiscal authority (henceforth, "the government"). Each household is endowed with one unit of the consumption good and $b$ maturing government bonds denominated in terms of monetary units (henceforth, "dollars"). Money is useful in this economy since households consumption is subject to a liquidity constraint. Consumption is the only argument in the households utility function, $u(c)$, whose first derivative is strictly positive.

The central bank is the monopolistic supplier of money in this economy. It lends dollars to the households before trade takes place at a cost of $r>0$ dollars per dollar borrowed. Thus, $r$ is naturally interpreted as the monetary policy instrument. A positive interest rate implies that the central bank obtains some profits in the form of consumption goods. We refer to these profits as seigniorage and assume that the central bank mechanically passes it to the government. The latter also collects lump-sum taxes from the households. Taxes and seigniorage finance government spending as well as the repayment of outstanding government bonds. Thus, the government flow of funds constraint is:

$$
\frac{B}{P}=T+S-G+\frac{B^{s}}{P}
$$

where $B>0$ is the initial stock of nominal government bonds, $P$ is the price level, $T \geq 0$ are taxes, $S \geq 0$ is seigniorage, $G \geq 0$ is government spending, and $B^{s}$ is the government supply of new bonds that, given that the economy only lasts one period, are never redeemed. Combining the funds constraint (1) with the transversality condition $B^{S}=0$, which states that the government does not supply new debt, we obtain the government intertemporal budget constraint which dictates that the net present value of inflows must equal the net present value of outflows:

$$
\frac{B}{P}=T+S-G
$$

We model the monetary exchange process by means of division of the entire period into several sub-periods or stages. As in Gale (2005), we divide the period into three stages:

Stage 1: Households borrow money from the central bank.

Stage 2: The central bank injects as much money as needed by the households to repay the monetary loans made in stage 1 and exchange of goods for dollars and dollars for goods takes place.

Stage 3: The government collects taxes and redeems bonds, households repay their loans to the central bank and private consumption and government spending take place.

Implicit in the above sequence is the fact that money is only used by households to acquire 
their consumption bundles. While keeping usage of money at a minimum level is inessential for the characterization of the Walrasian equilibria described later in this section, it greatly simplifies the analysis of the non-Walrasian version of this economy developed in the next section. In particular, in this section we assume that all taxes are paid using goods. This implies that the government enters stage 3 with no dollars but with the obligation to redeem dollar-linked bonds. Consistently with this, we assume that the government commits to redeem each bond in exchange for $1 / P$ consumption goods which can be directly consumed. That is, no further monetary exchange is needed for their consumption, or equivalently, maturing bonds are as liquid as dollars. Thus, the liquidity constraint takes the following form,

$$
c-\frac{b}{P} \leq \frac{m}{P}
$$

where $m$ denotes the agent's money balance borrowed from the central bank at the first stage. Implicit in this constraint is the assumption that dollars received by a household in exchange for his endowment cannot be used to acquire other households' goods. We use lower-case letters to denote variables referred to individual household choices and upper-case letters to denote their aggregate counterparts. ${ }^{5}$

The representative agent faces a decision problem in which he must choose a monetary loan, $m$, and a level of consumption, $c$, to maximize his utility function subject to the liquidity constraint (3) and the following flow of funds constraint,

$$
P c+r m \leq b+P(1-T)
$$

For strictly positive interest rates the flow of dollars that an agent receives in exchange for selling his endowment at stage 2 must exceed the amount borrowed from the central bank at stage 1 . As such difference persists at the aggregate, the central bank must inject additional money in an amount equivalent to the interest payment. That is, denoting by $M$ the (positive and finite) total amount of dollars borrowed by all agents in stage 1, the central bank injects $\Delta M$ dollars in the second stage, such that the settlement of monetary loans is just attainable, in the sense that $\Delta M=r M$. Thus, seigniorage is

$$
S=\frac{r M}{P}
$$

\footnotetext{
${ }^{5}$ For simplicity, government spending is not subject to any liquidity requirement. We briefly discuss the implications of relaxing the assumptions that taxes are payable in goods, that the government delivers goods in exchange for maturing bonds and that government spending is not subject to any liquidity requirement in section 5 .
} 
Definition 1 (competitive equilibrium). ${ }^{6} A$ competitive equilibrium is an allocation $(C, M), a$ vector of interest rate and prices $(r, P)$, and a government policy $(\Delta M, T)$, such that

(i) Given $(r, P)$ and $(\Delta M, T)$, the allocation $(C, M)$ maximizes $u(c)$ subject to constraints (3) and (4).

(ii) The government constraint (2) is satisfied.

(iii) Markets clear, i.e. $C+G=1$, and $m=M$.

In all cases analyzed later, we consider a monetary policy rule consisting of the central bank choosing an arbitrary positive interest rate, $r$, and simultaneously committing to select $\Delta M$ so as to meet the exact-attainability criterion listed above, i.e. $\Delta M=r M$. We refer to this rule as an interest rate peg. As for the fiscal policy rule, we introduce the following definition:

Definition 2 (Ricardian vs non-Ricardian policies). A government policy is Ricardian if it is formulated in such a way that the intertemporal budget constraint (2) is satisfied for any price. It is non-Ricardian if that equation is only satisfied in equilibrium. ${ }^{7}$

The following two propositions illustrate, by means of simple fiscal policies, the implications of these two alternative classes of policies in terms of the (in)determinacy of the equilibrium price level, as they are usually presented in the literature. ${ }^{8}$

Proposition 1 (Canonical Ricardian solution). Consider a Ricardian policy such that the central bank follows a interest peg rule and the government sets a price-invariant tax $T$. Then, the price level, $P$, and the level of government spending, $G$, are indeterminate.

Proof. Given the exogenous choices for $r$ and $T$ a competitive equilibrium is characterized by the following conditions:

(i) For given $P$ and $T$, household constraints (3) and (4) hold as equalities.

(ii) Given $M$, the central bank injects $r M$ dollars in the second stage.

(iii) Given $P$ and $r M$, the government sets $G$ so that the government budget constraint (2) holds.

(iv) Markets (goods and dollars) clear.

Let us consider an arbitrary positive and finite price $P^{R}$. It can be verified that there exists a

\footnotetext{
${ }^{6}$ All possible equilibria in this economy are symmetric.

${ }^{7}$ This definition corresponds to the one given by Woodford (1995).

${ }^{8}$ We use the term "canonical" here with reference to the class of Walrasian solutions of the model when it is assumed that the government can implement a Ricardian or non-Ricardian plan as just defined. Whether this a sensible assumption to be held under any circumstance is at the heart of the discussion on the validity of the FTPL's postulates, an issue which is analyzed in detail in the following sections.
} 
competitive equilibrium in which the government sets a $\operatorname{tax} T$, associated with such price, provided a sign condition holds. First, from the goods market clearing condition we learn that equilibrium households consumption satisfies $C=1-G$. Then, using (3) holding as an equality and the government budget constraint (2), we can solve for a unique level of government spending, for a given $P^{R}$,

$$
G=\frac{T+r}{1+r}-\frac{B}{P^{R}}
$$

The solution of this equation can be a part of a competitive equilibrium as long as $G \geq 0$, which tantamounts to impose that ${ }^{9}$

$$
P^{R} \geq P_{\min } \equiv \frac{1+r}{T+r} B
$$

Finally, equation (6) can then be exploited together with (3) to solve for the equilibrium stock of nominal balances:

$$
M=\frac{1-T}{1+r} P^{R}
$$

Proposition 1 makes clear that nominal indeterminacy associated with a monetary rule that leaves the determination of the stock of money, $M$, subject only to demand forces extends to fiscal indeterminacy under a Ricardian plan. As the real value of some fiscal outflows (namely, maturing bonds net of seigniorage) varies with the price level, the government must set a policy that makes its level of spending a function of the price, as made explicit by (6). This classical indeterminacy problem is resolved by the FTPL which exploits the latter relationship between nominal and real indeterminacy.

Proposition 2 (Canonical non-Ricardian solution). Consider a non-Ricardian policy such that the central bank follows an interest peg rule and the government sets some price-invariant levels of spending and taxes. Then, provided a sign condition holds, there is unique equilibrium price level consistent with such policy.

Proof. The conditions for the existence of a competitive equilibrium listed in the proof of proposition 1 are still required, except number (iii), as the fiscal rule now includes an exogenous tax. Using the market clearing and households optimality conditions, we learn that seigniorage in

\footnotetext{
${ }^{9}$ If the price would fall below $P_{\min }$, then the government would have to raise taxes above the initial target, even if $G=0$. For the ease of the exposition, we only consider prices that satisfy the lower bound in (7), so that in equilibrium the government does implement an exogenous tax. We follow this convention regardless of the nature of the policy, Ricardian or non-Ricardian. Also, notice that, since money is a fiat asset, nothing in principle precludes an equilibrium in which money is valueless. We henceforth restrict attention to monetary equilibria (i.e. equilibria with finite $P$ ).
} 
equilibrium is given by

$$
S=r\left(1-G-\frac{B}{P}\right)
$$

This expression shows that in equilibrium the central bank earns an amount of seigniorage equal to the interest rate times total monetary lending in real terms, which corresponds to the total economy's endowment (i.e. unity) minus the proportion of endowment that does not require monetary exchange (i.e. government spending and the value of maturing bonds). Plugging this expression into the government budget constraint (2) and rearranging yields

$$
\frac{B}{P}=\frac{T+r}{1+r}-G
$$

As every term in the right-hand side of this equality is exogenously set by fiscal $(G$ and $T)$ and monetary policy $(r)$, and $B>0$, there is a unique finite positive $P$ consistent with this policy rule provided $\frac{T+r}{1+r}-G>0$, which is the sign condition referred in the proposition. The solution is completed by solving for the equilibrium flow of dollars which is uniquely given from (8).

In providing supportive arguments, the proponents of the FTPL justify the interpretation of (2) as an additional separate equilibrium condition either by accepting that the government is limited on its actions by an intertemporal budget constraint, but with the extra qualification that the government is a "big player", so that it need not to take prices as given (see Woodford (1998, 2001)), or even by denying that such a constraint exists at all, arguing that (2) must be interpreted as a "government valuation equation" rather than as a constraint. Under this latter approach the government is viewed as a private firm whose equity is priced according to the future stream of profits, where an analogy is drawn between a firm's equity and the dollar-denominated government obligations, $B / P$, and between the firm's profit stream and the government's total surpluses (the RHS of (2)). From this perspective, the plausibility of non-Ricardian policies is accepted as it is the general idea that the future profits of a firm need not to be influenced by the current price of its shares and, therefore, equation (2) is only satisfied when the stock of the firm is correctly valued. This stock-analogy argument can be found, e.g., in Cochrane (2005), Christiano and Fiztgerald (2000) and Sims (1999).

Thus, most of the debate around the FTPL has centered on the following question: is it legitimate to treat (2) as a separate equilibrium condition rather than as a constraint? In what follows, we first provide an economic environment that allows for an uncontroversial distinction between equilibrium conditions and constraints and then show that the government can implement an exogenous level of spending and taxes (as in the policy of proposition 2) even if its actions are 
subject to a budget constraint like (2), as in proposition 1 .

\section{A non-Walrasian Version of the Economy}

In this section we depart from the Walrasian paradigm. The central idea is that markets are conceived as specialized trading posts in which market participants trade goods for assets and assets for goods. In particular, we consider a market concept similar to the one employed by Dubey and Geanakoplos $(1992,2006)$ and Bassetto (2002), and assume that a single pair of objects are exchanged at each market and participation is done by submission of specialized bids. Other elements, like preferences, initial endowments of goods and government bonds, are kept unchanged with respect to the economy of section 2. A liquidity constraint similar to (3) applies in this environment as well.

In order to maintain the competitive scheme for the household sector of the Walrasian economy, we assume that households individual actions are not observed by other households although aggregate actions, including the government ones, are common knowledge. As a consequence, each household anticipates that his individual actions will not bear any effect on any other agent's actions and, hence, on prices. We assume that each household that wishes to participate in a market must submit an unconditional bid containing the amount of dollars or goods that he wants to sell.

At the core of the mechanisms described later is the idea that the government may participate in some trading posts by setting prices together with upper limits in the volume of trade, rather than unconditionally offering quantities. The fact that the government is a large player makes the consideration of such class of bids a relevant issue at the aggregate level. ${ }^{10}$ This, however, does not interfere with the notion that budgetary restrictions that impose that the total amount of resources employed to back bids must be sufficient to honor the corresponding deliveries under any circumstance apply equally to all agents, irrespectively of their size which is the convention followed here.

In the Walrasian economy of the previous section dollars were only used to carry out two types of transactions: (i) goods being exchanged for dollars (and dollars for goods) between households, as prescribed by the liquidity constraint (3), and, (ii) households selling goods to the central bank in exchange for dollars. Here we retain the assumption that the government redeems maturing

\footnotetext{
${ }^{10}$ In a symmetric vein, we could allow a private agent to participate in a post by fixing prices and upper volumes of sold quantities. Yet, as long as such upper bounds are small at the aggregate, the equilibrium consequences will also be negligible.
} 
bonds for goods directly, but allow it to also exchange goods for money and vice versa. Although such transactions will never take place in the equilibria analyzed later, they will be an important part of what we describe below as a non-Ricardian fiscal strategy. Importantly, although we consider government transactions involving the exchange dollars, we maintain the assumption that the central bank chooses and implements its monetary policy independently of the government actions. In particular, we preclude any monetary loan to the government at all times, although we now allow for taxes payable in dollars. ${ }^{11}$ Also, we do not consider the case in which the government supplies new bonds and treat the transversality condition $B^{s}=0$ as an identity.

The role of the central bank is the same as in section 2. It sets an exogenous interest rate, supplies as many dollars as requested and then injects the exact amount of money that borrowers need to pay back their money withdrawals with interest, passing seigniorage to the government.

The sequence of events in this economy closely follows that of section 2 :

Stage 1. Households start with one unit of consumption goods and $b$ government bonds. The central bank sets a nominal interest rate $r>0$ and households borrow $m$ dollars.

Stage 2. Markets open and participants make their bids. We consider the following markets, each of which is characterized by the form of the bids submitted by the market participants:

Market 1. In this market (the private market) households exchange goods for dollars and dollars for goods. Each household may submit an unconditional sale bid for $m_{c}^{1}$ dollars and a sale bid for $c_{m}^{1}$ goods. We use subscripts to denote the object that the participant wishes to obtain in exchange for its sale bid (subscripts $m, c$, and $b$, stand for dollars, goods and government bonds, respectively) and later on we employ the superscript $g$ to refer to bids made by the government. Numerical superscripts denote the corresponding market .The price level in this market, denoted by $P$, is the ratio of the submitted quantities of goods and dollars,

$$
P=\frac{M_{c}^{1}}{C_{m}^{1}}
$$

The inverse of the price $P$ is naturally interpreted as the transactions value of money.

Market 2. The central bank makes sale bids of $r M$ dollars in exchange for goods, where $M$ is the total amount of dollars borrowed in stage 1. Each household may submit an unconditional sale

\footnotetext{
${ }^{11}$ We introduce here this form of taxation in order to allow the government to obtain dollars that at some point may be used to acquire consumption goods in a specialized trading post. In a more general setting, with a more sophisticated financial market, the government could also obtain dollars from private banks and from the sale of new debt.
} 
bid for $c_{m}^{2}$ goods. Thus, price in this market is given by

$$
P_{2}=\frac{r M}{C_{m}^{2}}
$$

Market 3. The government sets unilaterally the price, $P_{3}$, at which it is ready to buy dollars in exchange for goods, and each household may submit a sale bid of $m_{c}^{3}$ dollars, subject to the following constraint

$$
m_{c}^{1}+m_{c}^{3} \leq m
$$

Later on, we will allow for bids in which the government sets a price that may vary with some other variables in the economy. The government may also set an upper bound to the amount of goods delivered in exchange for dollars. We write the amount of goods actually pledged by the government, $C_{m}^{g, 3}$, as $C_{m}^{g, 3}=\min \left\{M_{c}^{3} / P_{3}, \bar{C}_{m}^{g, 3}\right\}$, where $\bar{C}_{m}^{g, 3}$ represents the aforementioned upper bound. Whenever $C_{m}^{g, 3}=\bar{C}_{m}^{g, 3}$, the exchange price, $P_{3}$, is determined as in a post with unconditional bids, i.e. $P_{3}=\frac{M_{c}^{3}}{\bar{C}_{m}^{g, 3}}$. Thus, we can write the corresponding market clearing condition as

$$
P_{3} C_{m}^{g, 3}=M_{c}^{3}
$$

bearing in mind that $P_{3}$ is set by the government if $C_{m}^{g, 3}<\bar{C}_{m}^{g, 3}$ and endogenously if $C_{m}^{g, 3}=\bar{C}_{m}^{g, 3}$. We henceforth refer to the inverse of $P_{3}$ as the fiscal value of money.

Market 4. In this post the government sets the price, $P_{4}$, at which it is ready to sell dollars in exchange for goods. Denoting by $C_{m}^{4}$ the amount of goods bid by households, the government submits a quantity of dollars $M_{c}^{g, 4}$, given by $M_{c}^{g, 4}=\min \left\{P_{4} C_{m}^{4}, \bar{M}_{c}^{g, 4}\right\}$, where $\bar{M}_{c}^{g, 4}$ stands for the maximum amount of dollars that the government is willing to sell on this post. As in market 3, if $M_{c}^{g, 4}=\bar{M}_{c}^{g, 4}$, then the exchange price in this post, $P_{4}$, is determined according to $P_{4}=\bar{M}_{c}^{g, 4} / C_{m}^{4}$. As before, the market clearing condition can be written generally as

$$
P_{4} C_{m}^{4}=M_{c}^{g, 4}
$$

and $P_{4}$ is referred as the fiscal value of goods.

For all the markets above and whenever the government does not set the price directly, we assume that prices are not defined if no bids are submitted in either side and sale bids that do not meet a counterpart are wasted. Otherwise, markets clear continuously regardless of the submitted bids.

Stage 3. The following events take place: 
(i) The government collects taxes in the form of goods, $T_{1} \in[0,1]$ and dollars, $T_{2} \geq 0$.

(ii) The government supplies goods in exchange for maturing bonds, whose value is linked to the transaction value of the dollar, $P$. Importantly, we assume that the government commitment to redeem bonds at their face value applies for any price level, $P$, and independently of whether the price is an equilibrium one or not. Thus, the amount of goods $C_{b}^{g}$, given in exchange for bonds presented for redemption, $B_{c}$, is computed as

$$
C_{b}^{g}=\frac{B_{c}}{P}
$$

A household may submit $b_{c}$ bonds for redemption subject to

$$
b_{c} \leq B
$$

(iii) The commitments to deliver goods and dollars made in previous stages are fulfilled.

(iv) Consumption and government spending take place.

Figure 1 summarizes the set of households and government actions during the period. The following flow of funds constraints ensure that every participant has enough resources to honor the central bank loans and sale bids under any circumstance:

- Households flow of goods constraint: ${ }^{12}$

$$
1+\frac{m_{c}^{1}}{P}+\frac{m_{c}^{3}}{P_{3}}+\frac{b_{c}}{P} \geq T_{1}+c_{m}^{1}+c_{m}^{2}+c_{m}^{4}
$$

The terms on the LHS are the household's inflows of goods: the initial endowment, goods obtained in exchange for dollars in markets 1 and 3 plus goods received in exchange for maturing bonds. The RHS contains the outflows of goods: tax payments, and sale bids in markets 1, 2 and 4 .

- Households flow of dollars constraint:

$$
m+P c_{m}^{1}+P_{2} c_{m}^{2}+P_{4} c_{m}^{4} \geq(1+r) m+m_{c}^{1}+m_{c}^{3}+T_{2}
$$

The inflows of dollars for the household are collected on the LHS: initial borrowing from the central bank plus dollars received in exchange for goods in markets 1, 2 and 4 . The RHS contains the outflows: redemption of initial central bank loan plus interest, dollars used in sale bids in markets

\footnotetext{
${ }^{12}$ In contrast to the Walrasian economy, we now consider the flows of goods and dollars separately as bids made in stage 2 convey the literal commitment to deliver a particular object.
} 


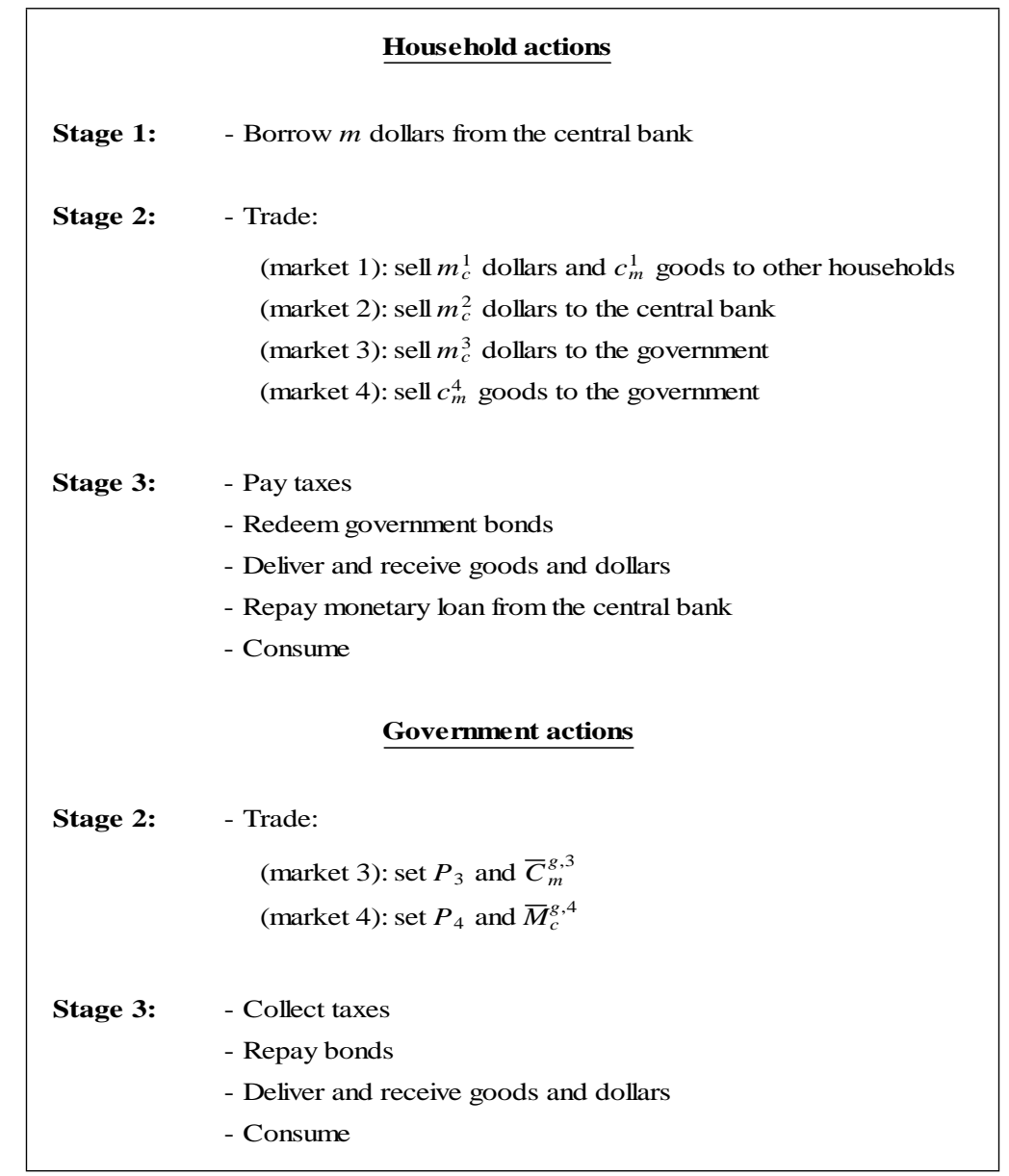

Figure 1: Timing and actions

1 and 3 and the dollar tax installment.

- Government flow of goods constraint:

$$
T_{1}+C_{m}^{2}+C_{m}^{4} \geq \frac{B_{c}}{P}+\frac{M_{c}^{3}}{P_{3}}
$$

Inflows of goods on the LHS include taxes, goods obtained by the central bank in market 2 (seigniorage) and households sales of goods in market 4. As for outflows, the government uses goods to redeem bonds and to obtain dollars market 3 .

- Government flow of dollars constraint:

$$
M_{c}^{3}+T_{2}=P_{4} C_{m}^{4}
$$

which states that the number of dollars obtained in market $3, M_{c}^{3}$, plus the dollar tax installment equal the amount of dollars required to support the government sale bids in market $4, P_{4} C_{m}^{4}$. Thus, 
we rule out the possibility that the government retains dollars at this stage since that would imply that the households sector at the aggregate cannot return the central bank loans with interest. ${ }^{13}$

Using the flow of goods constraint (17), we learn that household consumption, $c$, satisfies the following restriction

$$
c \leq 1+\frac{m_{c}^{1}}{P}+\frac{m_{c}^{3}}{P_{3}}+\frac{b_{c}}{P}-T-c_{m}^{1}-c_{m}^{2}-c_{m}^{4}
$$

and the following liquidity constraint that makes explicit that only goods obtained in exchange for assets can be consumed,

$$
c \leq \frac{m_{c}^{1}}{P}+\frac{m_{c}^{3}}{P_{3}}+\frac{b_{c}}{P}
$$

Using (19), we can write government spending as a residual of the government budget,

$$
G=T_{1}+C_{m}^{2}-\frac{B_{c}}{P}+C_{m}^{4}-\frac{M_{c}^{3}}{P_{3}}
$$

The sign restrictions in (17) and (19) ensure that $c \geq 0$ and $G \geq 0$, respectively.

We next provide the equilibrium notion used for this economy.

Definition 3 (symmetric competitive equilibrium). ${ }^{14}$ A symmetric competitive equilibrium is an allocation $\left(C, C_{m}^{1}, C_{m}^{2}, C_{m}^{4}, M, M_{c}^{1}, M_{c}^{3}, B_{c}, \Delta M, T_{1}, T_{2}, G, C_{m}^{g, 3}, C_{b}^{g}, M_{c}^{g, 4}\right)$, and interest rate and prices $\left(r, P, P_{2}, P_{3}, P_{4}\right)$, such that,

(i) Given $\left(r, P, P_{2}, P_{3}, P_{4}\right)$ and $\left(\Delta M, T_{1}, T_{2}\right)$, the allocation $\left(C, C_{m}^{1}, C_{m}^{2}, C_{m}^{4}, M, M_{c}^{1}, M_{c}^{3}, B_{c}\right)$ solves the household optimization problem:

$$
\begin{gathered}
\max u(c) \\
\left\{c, c_{m}^{1}, c_{m}^{2}, c_{m}^{4}, m, m_{c}^{1}, m_{c}^{3}, b_{c} \in \mathbb{R}_{+}^{8}\right\}
\end{gathered}
$$

subject to (12), (16), (17), (18), (21) and (22).

(ii) The government's solvency constraints (19) and (20) are satisfied.

(iii) Markets clear, i.e. equations (10), (11), (13) and (14) hold.

As customary in the literature on the FTPL, in the analysis that follows we do not consider any explicit government objective function and, rather, take as given a set of targets for the fiscal variables. What is important is that, regardless of how such fiscal targets are determined, the

\footnotetext{
${ }^{13}$ In fact, constraint (18) must hold as an equality for each household. To see this, notice that if (20) holds as an strict inequality then at least one other household would be violating his flow of dollars constraint.

${ }^{14}$ Without prior knowledge of the exact participants strategies we cannot rule out the existence of asymmetric equilibria.
} 
government ex ante commits to a particular strategy, by which we mean a conditional course of action that prescribes government actions under any conceivable eventuality.

Conditionality of government actions is a crucial feature of our environment and it is present in the equilibrium definition given above. To see this, notice that government solvency constraints (19) and (20) dictate that the amount of some funds flowing from and to the government is determined through the households actions. For example, as $P$ is determined by households bids $M_{c}^{1}$ and $C_{m}^{1}$ (see (10)), so it is the flow of goods that government delivers in terms of debt payments, $\frac{B_{c}}{P}$. In turn, this implies that government feasible choices of fiscal instruments like $G$ and $T_{1}$ can only be made meaningfully if conditional on the households actions.

\section{Equilibrium determinacy under non-Ricardian Strategies}

In this section we state the main result of the paper, namely, that in the context of the nonWalrasian economy of section 3 there exist government strategies that deliver equilibrium uniqueness. To this aim, we first provide a formal definition for government and household strategies.

Definition 4 (strategies). A government strategy is a bid price $P_{3}$ with a maximum bid $\bar{C}_{m}^{g, 3}$, a bid price $P_{4}$ with a maximum sale bid $\bar{M}_{c}^{g, 4}$, and tax installments $T_{1}$ and $T_{2}$, that satisfy (20) and (23). A household strategy is a monetary loan $m$, bids $\left\{c_{m}^{1}, c_{m}^{2}, c_{m}^{4}, m_{c}^{1}, m_{c}^{3}, b_{c}\right\}$ and a consumption level c, that satisfy (12), (16), (17), (18), (21), and (22).

We have not included $C_{m}^{g, 3}, M_{c}^{g, 4}, C_{b}^{g}$, and $G$ in the above definitions. Once the government specifies $\bar{C}_{m}^{g, 3}$ and $\bar{M}_{c}^{g, 4}$, the first two are not treated as separate choice variables. Given the nodefault assumption, $C_{b}^{g}$ can be deducted identically from (15) while $G$ is obtained as a residual from (23). Given the solvency constraints included in the above definition and the price equations (10), (11), (13) and (14), we learn that a government strategy is a function of the monetary policy rule $(r, \Delta M)$ and aggregate households actions $\left(C_{m}^{1}, C_{m}^{2}, C_{m}^{4}, M, M_{c}^{1}, M_{c}^{3}, B_{c}\right)$. A household strategy is a function of government actions $\left(P_{3}, \bar{C}_{m}^{g, 3}, P_{4}, \bar{M}_{c}^{g, 4}, T_{1}, T_{2}\right)$, the monetary policy rule and aggregate households actions.

In the spirit of the canonical cases of section 2, we next consider two alternative government strategies, each delivering a different outcome in terms of equilibrium determinacy. We still refer to such alternative strategies (rather than policies) as Ricardian and non-Ricardian. Also, in order to facilitate the comparison with the Walrasian economy, we assume that under both strategies, the government targets a constant total tax, as measured in terms of goods, $T=T_{1}+T_{2} / P$, and 
denote such target by $\widetilde{T}$. Also, we assume that the government seeks no participation in markets 3 and 4, thus setting $\widetilde{\bar{C}}_{m}^{g, 3}=\widetilde{\bar{M}}_{c}^{g, 4}=0$, where $\widetilde{\bar{C}}_{m}^{g, 3}$ and $\widetilde{\bar{M}}_{c}^{g, 4}$ stand for the targeted upper trade limit in markets 3 and 4, respectively. According to the government flow of dollars constraint (20), this latter assumption implies that the target for the dollar-tax must satisfy $\widetilde{T}_{2}=0$. Importantly, government targets are understood as objectives to be met in equilibrium, but not necessarily out of it. In particular, we exploit the potential deviations of both $C_{m}^{g, 3}$ and $M_{c}^{g, 4}$ with respect to their targets to provide a distinction between Ricardian and non-Ricardian strategies that specialize the canonical definition of Ricardian and non-Ricardian policies (definition 2) to the current nonWalrasian context.

Definition 5 (Ricardian vs non-Ricardian strategies). A government strategy is Ricardian if $\bar{C}_{m}^{g, 3}=\bar{M}_{c}^{g, 4}=0$ for any $P$, or, equivalently, if

$$
G=T_{1}+C_{m}^{2}-\frac{B_{c}}{P}
$$

holds for any $P{ }^{15}$ It is non-Ricardian if $\bar{C}_{m}^{g, 3}=\bar{M}_{c}^{g, 4}=0$, i.e. (24), is only satisfied in equilibrium.

Proposition 3 (A Ricardian fiscal strategy). Suppose that the government sets $T=\widetilde{T}$ and $\bar{C}_{m}^{g, 3}=\bar{M}_{c}^{g, 4}=0$ for any $P$. Then the equilibrium price, $P$, and the level of government spending are indeterminate.

Proposition 4 (A non-Ricardian fiscal strategy). Suppose that there exists a competitive equilibrium with $T=\widetilde{T}, \bar{C}_{m}^{g, 3}=\bar{M}_{c}^{g, 4}=0$, and $G=\widetilde{G}$, where $\widetilde{G}$ is a government exogenous target for $G$. Then, there exists a government strategy such that the unique equilibrium contains $T=\widetilde{T}$, $G=\widetilde{G}$, and $\bar{C}_{m}^{g, 3}=\bar{M}_{c}^{g, 4}=0$.

We describe below the intuition behind these propositions and relegate the complete proof to the appendix.

Regardless of the particular government strategy, household optimal behavior requires that (12), (16), (18), (21) and (22) hold as equalities. When (21) and (16) hold as equalities the household does not leave unconsumed goods and redeems all his bonds, respectively. Also, as $r>0$, it is not optimal to borrow more dollars from the central bank than strictly needed to acquire consumption goods and, hence, (12) and (22) both must hold as equalities in the solution of the household maximization problem. Likewise, it cannot be optimal to end up with a positive

\footnotetext{
${ }^{15}$ As in the analysis of section 2 , hereafter we restrict the set of potential prices $P \geq P_{\min }$.
} 
amount of dollars so that (18) holds as an equality, as well. Also, optimal individual household bids imply that the aggregate counterparts $M_{c}^{1}, C_{m}^{1}, C_{m}^{2}$ are such that that $P=P_{2}$, for otherwise there would exist opportunities to increase individual consumption. Thus, in equilibrium, the following set of equalities, that include the latter condition $P=P_{2}$ plus the aggregate counterparts of (12), (16), (21) and (22), hold

$$
\begin{aligned}
P & =P_{2} \\
M & =M_{c}^{1}+M_{c}^{3} \\
B & =B_{c} \\
C & =1+\frac{M_{c}^{1}}{P}+\frac{M_{c}^{3}}{P_{3}}+\frac{B_{c}}{P}-T_{1}-C_{m}^{1}-C_{m}^{2}-C_{m}^{4} \\
M+P C_{m}^{1}+P_{2} C_{m}^{2}+P_{4} C_{m}^{4} & =(1+r) M+M_{c}^{1}+M_{c}^{3}+T_{2} \\
C & =\frac{M_{c}^{1}}{P}+\frac{M_{c}^{3}}{P_{2}}+\frac{B_{c}}{P}
\end{aligned}
$$

Consider first the Ricardian strategy of proposition 3. Such strategy implies that at stage 3 the government simply adjusts its level of spending so that (23) holds as an identity for any price $P$, since there are no other available actions given the price-invariant tax policy and the commitment to not participate in markets 3 and 4 . Then, the argument in proposition 1 applies here too. That is, for any price $P \geq P_{\text {min }}$, we can find an allocation that satisfies the government constraints (20) and (23), markets 1 and 2 clearing conditions (10) and (11), respectively, and all the equalities in (25), after imposing $M_{c}^{3}=C_{m}^{4}=0$.

Next, we provide an example of a government non-Ricardian strategy that delivers equilibrium uniqueness in the context of proposition 4. Of course, we do not claim that such strategy is the only one that produces that result. In order to emphasize the differences with respect the previous Ricardian strategy, in what follows, we name an arbitrary price level $P$ and verify that there exist feasible government actions that rule out such price as an equilibrium one even if each household follows a strategy such that all the equalities in (25) hold (case 1 below). We then complete the strategy by considering the case in which at least one equality in (25) does not hold (case 2 below).

Case 1 (non-Ricardian deviations). Let us first compute the price level, $\widetilde{P}$, in the competitive equilibrium in which government actions coincide with their targets to find that

$$
\widetilde{P}=B\left[\frac{\widetilde{T}+r}{1+r}-\widetilde{G}\right]^{-1}
$$


which naturally coincides with the FTPL canonical solution in proposition 2. Assuming that all the equalities in (25) hold, let us define the government excess surplus, denoted by $X$, as the difference between the target $\widetilde{G}$ and the level of government spending that would result, for a given $P$, under the Ricardian strategy of proposition 3 , which we denote by $G^{R}$, for Ricardian. Then, using the government flow of funds equation (23) and markets 1 and 2 clearing conditions, we can express the excess surplus as

$$
X \equiv G^{R}-\widetilde{G}=B\left(\frac{1}{\widetilde{P}}-\frac{1}{P}\right)
$$

which is positive (negative) for $P>(<) \widetilde{P}$, reflecting the fact that the real value of government debt is positively linked to the value of the dollar. Let us consider the following government strategy, distinguishing across the two possible contingencies outlined above, i.e. $P>\widetilde{P}$ and $P<\widetilde{P}$.

1. Low transactions value of money. Suppose first that the price in the private market is $P>\widetilde{P}$, i.e. there is a positive excess surplus. Then, the government sets a fiscal value of money $P_{3}^{-1}=P^{-1}+d_{m}$, for $d_{m}>0$, i.e. it is willing to purchase dollars giving goods in exchange and paying a more advantageous price than the private market does. Such an action is feasible, in the sense that it respects the government resource constraint (19) for any size of the aggregate bid $M_{c}^{3}<M$, as long as $d_{m}$ is not too high. A particularly simple specification that meets the latter requirement under any circumstance is $d_{m}=X / M$. In words, the government is willing to pay a price premium for each dollar in the economy by distributing the excess surplus across the entire money stock. ${ }^{16}$ Thus, as $P>\widetilde{P}$ the government uses the inflow of goods in excess of its planned expenditure to increase the total demand for dollars. Critically it does so in a way that makes suboptimal, from a household perspective, to supply dollars in the private market: the household could consume more by submitting the same amount of dollars to market 3. Hence, under this strategy there cannot be an equilibrium with $P>\widetilde{P}$.

The remaining actions of the government are as follows. It sets $T=T_{1}=\widetilde{T}$ and $T_{2}=\widetilde{T}_{2}=0$, i.e. when facing a positive unplanned surplus the government need not to increase taxes, distributing the extra unplanned surplus using goods sale bids in market 3 instead. Also, the government sets a fiscal value of goods $P_{4}=P$ with $\bar{M}_{c}^{g, 4}=M_{c}^{3}$, which allows the inflow of dollars obtained in market 3 to remain in the economy so that initial central bank loans can be fully repaid in stage 3 , thus respecting the assumption that the government flow of dollars constraint (20) holds as an equality. Also, as the government obtains $1 / P$ goods per dollar received in market 3 and supplied in market 4 , it finances a portion $P^{-1}$ of the fiscal value $P_{3}^{-1}$ that is not financed out of the excess surplus (this latter portion is $d_{m}$ ).

\footnotetext{
${ }^{16}$ Thus, the government does not need to impose an explicit upper bound, $\bar{C}_{m}^{g, 3}$.
} 
Government spending, which is derived mechanically from (23), satisfies

$$
G=\widetilde{T}+r\left[1-G-\frac{B}{P}\right]-\frac{B}{P}-M_{c}^{3} d_{m}=\widetilde{G}+X-\frac{1}{1+r} M_{c}^{3} d_{m}
$$

where the term $r[1-G-B / P]$ corresponds to seigniorage and the second equality follows from the definition of the excess surplus in (27). Equation (28) makes explicit that government expenditure at an off-equilibrium price $P>\widetilde{P}$ is strictly larger than the target in an amount corresponding to the undistributed excess surplus, $X-\frac{1}{1+r} M_{c}^{3} d_{m} \cdot{ }^{17}$

Finally, the government ceases to participate in markets 3 and 4 , thus setting $\bar{C}_{m}^{g, 3}=\bar{M}_{c}^{g, 4}=0$, when $P=\widetilde{P}$.

2. High transactions value of money. Consider a price $P<\widetilde{P}$. The government reacts by making a dollars sale bid at a lower price, in terms of goods, than the one prevailing in the private market. An obvious valid example of such price is $P_{4}=\widetilde{P}$. Feasibility of that bid requires that the government obtains $\widetilde{P} C_{m}^{4}$ dollars for a given aggregate household bid $C_{m}^{4}$, which can be done by setting a tax $T_{2}=\widetilde{P} C_{m}^{4}$ and not participating in market 3 , i.e. $\bar{C}_{m}^{g, 3}=0 .{ }^{18}$ This ensures that the flow of dollars constraint (20) holds for any $P$.

As regards the choice of $T_{1}$, we consider two separate cases:

i) If $P$, while lower than $\widetilde{P}$, is sufficiently high (in the precise sense given below), then the government can follow a tax policy that keeps total taxes at their targeted level, $\widetilde{T}$, by reducing $T_{1}$ to compensate a positive $T_{2}$, i.e. $T_{1}=\widetilde{T}-\frac{\widetilde{P}}{P} C_{m}^{4}$. In that case the budget constraint (23) reveals that $G$ satisfies

$$
G=\widetilde{T}-\frac{\widetilde{P}}{P} C_{m}^{4}+r\left[1-G-\frac{B}{P}\right]-\frac{B}{P}+C_{m}^{4}=\widetilde{G}+X-\frac{1}{1+r} C_{m}^{4} d_{c}
$$

where $d_{c}$, which is defined as $d_{c} \equiv \frac{\widetilde{P}}{P}-1$, represents the premium paid by the government on goods in market 4 with respect to the price prevailing in the private market. However, a constant level of taxation $\widetilde{T}$ is feasible only as long as government spending resulting from (29) takes non-negative values. In particular, a tax policy that sets $T=\widetilde{T}$ ceases to be feasible if $P<P_{0}$, where $P_{0}$ is the price level that, for a given $C_{m}^{4}$, makes $G=0$ in (29). Exploiting this latter condition together

\footnotetext{
${ }^{17}$ The undistributed excess surplus includes the increase in seigniorage due to the correspondingly larger monetary injections required to sustain households bids in market 3, as dictated by (12). Such positive variation in seigniorage amounts to $\frac{r}{1+r} M_{c}^{3} d_{m}$. Thus, total undistributed surplus becomes $X-\frac{1}{1+r} M_{c}^{3} d_{m}$.

${ }^{18}$ As we assume an unlimited ability by the government to collect taxes in the form of dollars, it does not need to impose an upper limit to the volume of dollar sale bids in market 4 to guarantee its solvency in that trading post.
} 


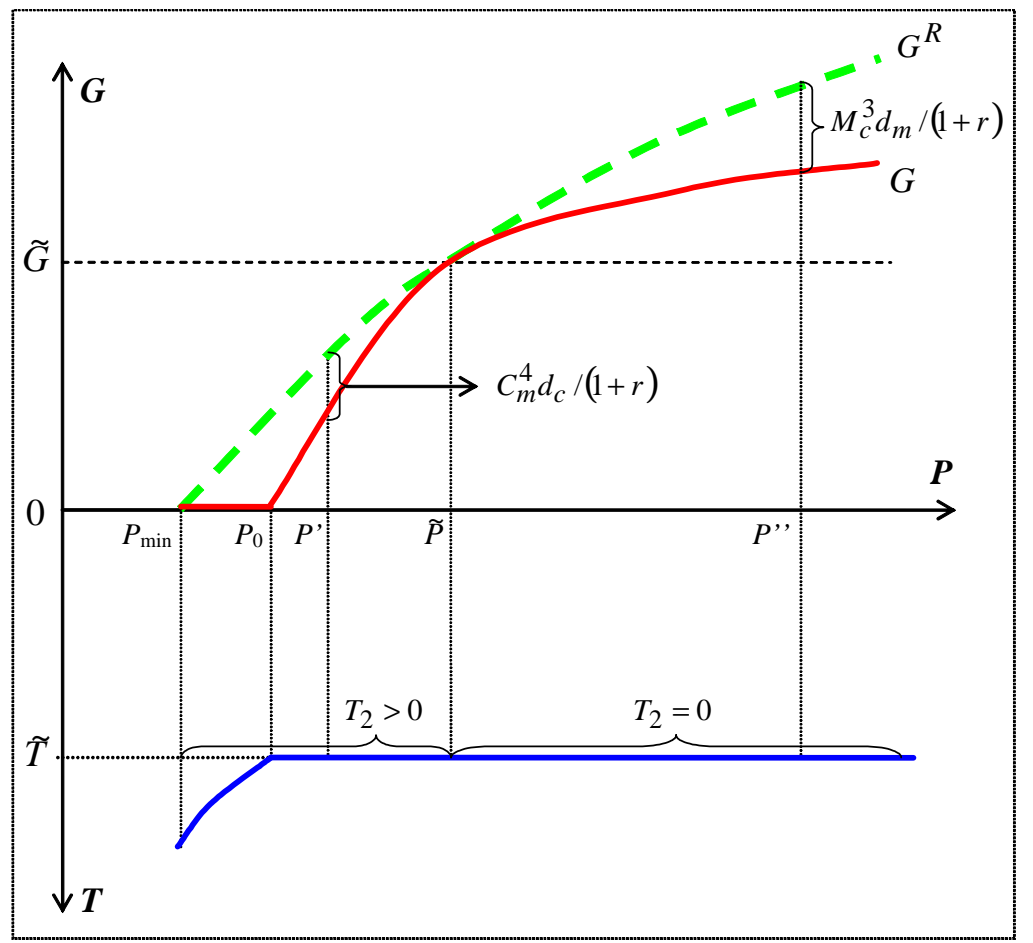

Figure 2: Non-Ricardian deviations

with (26) and (27), we can write $P_{0}$ as

$$
P_{0}=\frac{(1+r) B}{\widetilde{T}+r-C_{m}^{4} d_{c}}
$$

ii) If $P<P_{0}$, the government sets $G=0$ and raises taxes $T_{1}$ as much as required to redeem bonds at their face value. Specifically, the level of $T_{1}$ that is consistent with the government budget (23) as $G=0$ and (25) holds is given by

$$
T_{1}=\frac{B}{P}-r\left(1-\frac{B}{P}\right)-C_{m}^{4}
$$

Thus, in both cases i) and ii), as $d_{c}>0$, the government strategy rules out any $P<\widetilde{P}$.

Figure 2 depicts graphically the set of government actions just described. The upper panel contains the level of government spending consistent with the strategy just described (solid line) as a function of the private market price, $P \geq P_{m i n}$, and for some given households bids $M_{c}^{3}$ and $C_{m}^{4}$. This panel also depicts the function $G^{R}$ (discontinuous line). The lower panel contains the total level of taxation, $T$, specifying whether the government collects taxes in the form of dollars $\left(T_{2}>0\right)$ or not $\left(T_{2}=0\right)$. For prices higher than $\widetilde{P}$, like $P^{\prime \prime}$, the government keeps taxes at their 
target, $T_{1}=\widetilde{T}$ and $T_{2}=0$. Tax inaction in this region is a feasible choice because, on the one hand, at a price $P^{\prime \prime}$, the government would receive more goods than strictly necessary to pay its debt and maintain a non-negative level of spending and, on the other, because the government is willing to sell goods in market 3 . For prices falling within the interval $\left[P_{0}, \widetilde{P}\right)$, like $P^{\prime}$ in the figure, total taxes are set at their target, $\widetilde{T}$, but now the government must deviate from the targeted tax-composition, as in this price-region the government is willing to sell dollars in market 4, which are obtained by raising $T_{2}$ above the target. For prices in the interval $\left[P_{\min }, P_{0}\right)$ the non-negativity constraint on $G$ is binding and the government is forced to adjust total taxes so as to make feasible its commitment to buy goods at a price with a positive premium with respect to the private market. In all cases, given the tax choices, the government must set a level of spending that falls below the one that would correspond to a Ricardian plan, i.e. $G^{R}=\widetilde{G}+X .{ }^{19}$

It is worth stressing that, like in the FTPL, with this government strategy the government avoids a fiscal policy that mechanically links the total fiscal surplus $(T-G+S)$ to the real value of its debt. On the contrary, as the government allows for trade in markets 3 and 4 in the way just described, nothing ensures that (24) holds under every circumstance. We hence refer to the deviations of the government actions with respect to their targets in markets 3 and 4 as non-Ricardian, as opposed to the case analyzed next.

Case 2 (Ricardian deviations). Consider the case in which at least one of the equalities in (25) holds as a strict inequality. If so, then, at least one household is not behaving optimally and the corresponding allocation and price level cannot be part of an equilibrium, regardless of whether the government participates in markets 3 and 4. Although the government is forced to react in such eventuality in order to satisfy its budget constraint, it can do so by means of a pure Ricardian adjustment, i.e. adjusting its primary surplus to guarantee solvency without participating in market 3 or 4 . For example, if $B_{c}<B$ (i.e. some households fail to redeem their entire stock of bonds) the government will face an unplanned decrease in its goods outflow equal to $\left(B-B_{c}\right) / P$. It can commit to distribute such extra resources uniformly across households by simply reducing taxes and does not need to implement a non-Ricardian action, as in case 1 above, to rule out such eventuality as an equilibrium.

\footnotetext{
${ }^{19}$ Notice that the vertical distance between the $G$ and $G^{R}$ schedules can be made arbitrarily small by setting low (while positive) values for $d_{m}$ and $d_{c}$ (by e.g. scaling down those given in the main text by a constant term arbitrarily close to zero). This illustrates two interesting features of this government strategy. First, if $d_{m}$ and $d_{c}$ are close to zero, the government may maintain the targeted level of taxes, $\widetilde{T}$, like in the Ricardian strategy of proposition 3 , and set $G$ close to $G^{R}$ too. Thus, both the non-Ricardian and Ricardian strategies would be almost observationally equivalent with respect to the response of the primary surplus to changes in $P$. Yet, in the former case, there is only one equilibrium price. Second, as $d_{m}$ and $d_{c}$ are small, so it is the net (off-equilibrium) consumption of resources needed by the government to sustain its bids in markets 3 and 4 .
} 
The following tax adjustment, $\Delta_{T}$, that takes into account the possibility that, due to suboptimal households actions, the flows of goods corresponding to debt redemption and seigniorage differ from the ones compatible with (25), makes the government strategy feasible in such an event,

$$
\Delta_{T}=\frac{B_{c}-B}{P}+r\left[\left(1-G-\frac{B}{P}\right)-\frac{M}{P_{2}}\right]
$$

The first term on the RHS captures the downwards adjustment in the government outflow of goods due to a suboptimal households bid $B_{c}<B$. The second term represents the corresponding variation in seigniorage that arises when some households bids are such that at least one equality in (25) does not hold.

We are now in a position to write down the complete government strategy that nests the two types of potential deviations analyzed above.

Corollary to proposition 4 (a non-Ricardian strategy). If the government adopts the following strategy, then there exists a unique competitive equilibrium with $T=\widetilde{T}, T_{2}=0, G=\widetilde{G}$, $\bar{C}_{m}^{g, 3}=\bar{M}_{c}^{g, 4}=0$, and $P=\widetilde{P}$,

If $P \begin{cases}>\widetilde{P}, & \text { set } P_{3}=\left(P^{-1}+d_{m}\right)^{-1} ; d_{m}=\frac{X}{M} ; P_{4}=P ; \bar{M}_{c}^{g, 4}=M_{c}^{3} ; T_{2}=0 ; T=\widetilde{T}+\Delta_{T} \\ =\widetilde{P}, & \text { set } \bar{C}_{m}^{g, 3}=0 ; \bar{M}_{c}^{g, 4}=0 ; T_{2}=0 ; T=\widetilde{T}+\Delta_{T} \\ \in\left[P_{0}, \widetilde{P}\right), & \text { set } \bar{C}_{m}^{g, 3}=0 ; P_{4}=\widetilde{P} ; T_{2}=\widetilde{P} C_{m}^{4} ; T_{1}=\widetilde{T}-\frac{\widetilde{P}}{P} C_{m}^{4}+\Delta_{T} \\ \in\left[P_{\min }, P_{0}\right), & \text { set } \bar{C}_{m}^{g, 3}=0 ; P_{4}=\widetilde{P} ; T_{2}=\widetilde{P} C_{m}^{4} ; T_{1}=\frac{B}{P}-r\left(1-\frac{B}{P}\right)-C_{m}^{4}+\Delta_{T}\end{cases}$

\section{Discussion}

In this section we first discuss the previous determinacy result in the light of some arguments contained in the previous literature and check the potential of our approach to clarify some of the most controversial questions around the FTPL, focusing on the nature of the government intertemporal budget equation and the fiscalist stock analogy. Then, we comment on some possible extensions. 


\subsection{This paper and the FTPL}

Equilibrium conditions versus budget constraints. At the core of the definition of a nonRicardian policy is the idea that the government intertemporal budget constraint (2) may not hold for some prices, thus admitting that it is an equilibrium condition rather than an identity. Buiter (2002) argues that such a view is an economic misspecification. The approach followed here offers a neat resolution to this controversy. Equation (23) is a budget constraint that must be respected both in and out of equilibrium, as stressed by Buiter. The following equation, that represents a particular case of (23) in which all government choice variables are set at their respective targeted values and all the equalities in (25) hold,

$$
\widetilde{G}=\widetilde{T}+r\left(1-\widetilde{G}-\frac{B}{P}\right)-\frac{B}{P}
$$

is an equilibrium condition if the government commits to the non-Ricardian strategy presented above. As such, it only holds for a single price, $\widetilde{P}$.

There is an obvious similarity between the role played by the transversality condition $\left(B^{s}=0\right)$ in the arguments put forward by the proponents of the FTPL and our approach. In the former case $B^{s}$ is allowed to take values different from zero under some contingencies, much as in our economy the terms $C_{m}^{4}$ and $\frac{M_{c}^{3}}{P_{3}}$ in $(23)$ are allowed to take positive values. Yet there are two critical differences with respect to the FTPL. First, $G$ and $T$ in (23) need not to coincide with their targeted values (indeed, they will not coincide for most prices) since some government actions must necessarily be conditional on households actions. Second, in our setting the government defeats some prices as equilibrium ones through feasible actions in markets 3 and 4 . This is in clear contrast with the idea that the government can rule out some potential equilibria by creating an excess supply of irredeemable bonds.

The fiscalist stock-analogy. The non-Ricardian strategy outlined above prescribes a government action in the event of a price $P>\widetilde{P}$ similar to the one considered by Wallace (1981) and Obstfeld and Rogoff (1983), as the government uses its unplanned surplus to avoid an excessive depreciation of the dollar. It may be argued, along the lines of Cochrane (2005) and Sims (1999), that a dollar then becomes a residual claim to the government surplus. In fact, under this perspective, the difference between the transactions and the fiscal value of a dollar $\left(d_{m}\right)$ can be seen as a dividend paid to money holders that sell dollars in market 3. However, as opposed to the FTPL, the government strategy considered here is successful in ruling out potential equilibria with $P>\widetilde{P}$ precisely because the government does not commit to keep $G$ and $T$ simultaneously 
at their targeted levels in view of $P$. As the government offers the possibility of delivering goods in exchange for dollars, it must let its level of expenditure go above the target as long as such possibility is not fully exhausted. In other words, the government must allow for undistributed profits when $P>\widetilde{P}$.

In our economy, the previous device does not work symmetrically, however. The announcement by the government that it will pay a price per dollar lower than what the private market is already paying (say, by setting $d_{m}<0$ in market 3) need not have any effect. In the event of a price $P<\widetilde{P}$, the non-Ricardian strategy outlined before indicates that the government engineers a plan that results in a depreciation of the dollar while avoiding a direct monetization of the deficit, as in the fiscal-dominance case of Sargent and Wallace (1981). This is done be means of a dividend on goods, $d_{c}$, paid in market 4 .

Thus, the idea that a government may unconditionally stick to a low fiscal surplus in the hope that the price level will automatically rise enough so as to erode the real value of its obligations does not apply here. Specifically, fiscalist hyperinflations as the one highlighted by Kocherlakota and Phelan (1999) as a FTPL's anomaly, along which money becomes valueless because the government plans a stream of zero surpluses in face of a positive initial debt are not possible in our environment. If a firm's shares are valued because e.g. they facilitate transactions, in addition to being a residual claim of the firm's profits, then the firm may go bankrupt but its shares may still have a positive value. This last point illustrates an important difference between a cash-less economy, in which money only exists as a unit of account, and the monetary economy of this paper. In the former, if the government runs a zero surplus, hence no offering any positive amount of goods in exchange for a maturing dollar-denominated bond, both the bond and the dollar (as unit of account) must be valueless in equilibrium. In a genuine monetary economy, a zero total surplus may be compatible with a situation in which dollars (as mean of exchange) are still positively valued while the bond is not (i.e. in such a case the government must default on its debts).

\subsection{Limitations and extensions}

We have make a number of seemingly restrictive assumptions. Specifically, we have considered taxes that are payable in goods and bonds that give their holders the right to redeem them directly in exchange for goods. Both assumptions have direct consequences on the government budget, in the sense that by removing the need for using money to repay bonds and to meet the goods-tax obligation, total seigniorage is likely to fall (recall that in all the equilibria analyzed in the paper, money is only used to overcome the households liquidity constraint). Yet, none of the arguments 
of the paper hinge on the size of seigniorage. Thus, we believe that validity of the class of nonRicardian strategies presented in this paper would extend to a richer environment featuring taxes that are only payable in dollars, government bonds that promise to deliver dollars at maturity and, possibly, a liquidity constraint affecting government spending.

We have also ruled out the possibility of any form of intra-period credit except monetary loans made by the central bank to the households. Such assumption poses somewhat unrealistic constraints to the government. In particular, in our economy the central bank does not accept government bonds in exchange for dollars and the government cannot borrow money directly from the central bank or the private sector. If anything, introducing these forms of government credit would tend to provide the government with extra tools to implement its fiscal targets through a non-Ricardian strategy.

We believe that the most interesting extension is the introduction of multiple periods and, possibly, an infinite horizon economy. Such extension would allow for intertemporal trade being implemented through sales of new government bonds. Then, trade that in our stylized model occurs in markets 3 and 4 , could be envisaged as taking place in a newly-issued debt market. That is, rather than committing to contemporaneous deliveries of goods and dollars in markets 3 and 4 , respectively, the government could then trade promises of future deliveries of these objects.

\section{Conclusion}

In this paper we show that there exist feasible fiscal strategies that deliver a unique equilibrium price level under an interest rate peg. Such fiscal strategies satisfy a government intertemporal budget constraint under any circumstance, thus departing from the fiscal theory of the price level that, in some cases, asserts that such constraint can be violated while, in others, denies its existence. Still, the along the fiscal strategies considered in this paper the government avoids a fiscal policy that mechanically links its surplus to the real value of its outstanding nominal debt, much in the spirit of the standard fiscal theory.

The non-Ricardian fiscal strategies analyzed here share some features with a number of studies on equilibrium selection mechanisms in the monetarist tradition, like those in Wallace (1981) and Obstfeld and Rogoff (1983). As in those papers, there are potentially more than one equilibrium and the government targets a particular one. To achieve its fiscal targets, the government reacts to an excessive depreciation of the currency by selling goods in exchange for dollars in a way that creates divergence of prices across different markets for the same items. Conversely, the 
government buys goods in exchange for dollars to rule out potential equilibria in which the value of the dollar is above the one consistent with its targets. We show that such fiscal actions can be implemented without resorting to direct monetization of the deficit, thus respecting the assumption of independent fiscal and monetary authorities. In terms of the "game of chicken" of Sargent and Wallace (1981), under a non-Ricardian strategy the fiscal branch of the government blinks for all prices but one: the equilibrium one.

The theory of this paper rests heavily on the description of the actions taken by the government out of the equilibrium. To provide a transparent distinction between restrictions that must be respected even out of equilibrium versus genuine equilibrium conditions, we cast our arguments into a model of a non-Walrasian monetary economy in which the price formation mechanism is explicitly modelled. 


\section{Appendix: Proof of claims in section 4}

\section{Proof of proposition 3.}

Given a government strategy that includes $T=\widetilde{T}$ and $\bar{C}_{m}^{g, 3}=\bar{M}_{c}^{g, 4}=0$, a symmetric equilibrium is characterized by the following set of conditions:

i) Given $P, P_{2}, r$ and $\widetilde{T}$, households constraints (12), (16), (18), (21) and (22) hold as equalities, with $M_{c}^{3}=C_{m}^{4}=0$. Also, utility maximization requires that $P=P_{2}$.

ii) The government solvency constraints (19) and (20) hold.

iii) Markets 1 and 2 clear.

We next consider an arbitrary $P \geq P_{\min }$ and verify that there exists an equilibrium for which the above conditions are satisfied. Using the equilibrium conditions $B=B_{c}, P=P_{2}, M=M_{c}^{1}$, and $\frac{M_{c}^{1}}{P}=C_{m}^{1}$, we combine the aggregate counterpart of the households and the government flow of goods constraints, (21) and (19), respectively, to find that, in equilibrium, $C+G=1$, i.e. all resources are consumed. We plug this last equality into the government constraint (19) and solve for government spending, $G^{R}$ :

$$
G^{R}=\frac{\widetilde{T}+r}{1+r}-\frac{B}{P}
$$

which is non-negative as long as $P \geq P_{\min }$ (where now $P_{\min }$ is understood as evaluated at $T=\widetilde{T}$ ). Thus, equilibrium households consumption satisfies $C=1-G^{R}$. Given $P$, we use the liquidity constraint (22) to solve for the monetary stock $M$, to find that $M=P\left(1-G^{R}\right)-B$. Finally, we can solve for $C_{m}^{2}$ using the equilibrium condition $P=P_{2}$ together with market 2 clearing condition, to find that $C_{m}^{2}=\frac{r M}{P}$.

\section{Proof of proposition 4 .}

We first characterize the unique symmetric competitive equilibrium that contains the government policy targets, i.e. $T=\widetilde{T}, G=\widetilde{G}$, and $\bar{C}_{m}^{g, 3}=\bar{M}_{c}^{g, 4}=0$. The solution of the household's optimization problem satisfies equations (12), (16), (21), (22) and (18) holding as equalities. Also, as $\bar{C}_{m}^{g, 3}=\bar{M}_{c}^{g, 4}=0$, the household optimally sets $m_{c}^{3}=c_{m}^{4}=0$. Government expenditure satisfies

$$
\widetilde{G}=\widetilde{T}+C_{m}^{2}-\frac{B}{\widetilde{P}}=\widetilde{T}+r \frac{M}{\widetilde{P}}-\frac{B}{\widetilde{P}}
$$

where $\widetilde{P}$ is the equilibrium price level and the second equality is obtained after combining market clearing condition (11) with the equilibrium condition $P_{2}=P$. Then, exploiting the equilibrium condition $1=C+\widetilde{G}$ together the aggregate counterpart of the liquidity constraint (22), we rewrite $(35)$ as

$$
\widetilde{P}=B\left[\frac{\widetilde{T}+r}{1+r}-\widetilde{G}\right]^{-1}
$$

which is equation (26) in the text, and solve for the equilibrium money supply to find that $\widetilde{M}=$ $\widetilde{P}(1-\widetilde{G})-B$. From the market clearing conditions (10) and (11), we obtain aggregate equilibrium bids $C_{m}^{1}=\widetilde{M} / \widetilde{P}$ and $C_{m}^{2}=r \widetilde{M} / \widetilde{P}$.

Clearly, beside the unique symmetric equilibrium, there may exist other non-symmetric ones, since individual bids $c_{m}^{1}$ and $c_{m}^{2}$ need not coincide with the corresponding aggregate ones. That is, two different households, say $i$ and $j$, may achieve the same level of consumption in equilibrium by making different bids in markets 1 and 2, i.e. $P\left(c_{m}^{1, i}+c_{m}^{2, i}\right)=P\left(c_{m}^{1, j}+c_{m}^{2, j}\right)$, with $c_{m}^{1, i} \neq c_{m}^{1, j}$. 
In order to solve for the government excess surplus, $X$, we combine (34) and (35), using the equilibrium value of $\widetilde{M}$, to arrive at the expression given in the main text, $X \equiv G^{R}-\widetilde{G}=$ $B\left(\frac{1}{\widetilde{P}}-\frac{1}{P}\right)$.

We next show that there cannot be an equilibrium with $P>\widetilde{P}$ if the government commits to the non-Ricardian strategy presented in the corollary of proposition 4 . We focus on the case in which $(25)$ holds. ${ }^{20}$ For $P>\widetilde{P}$ the government participates in market 3 setting $P_{3}$ such that $P_{3}^{-1}=P^{-1}+d_{m}$ and $d_{m}=X / M>0$. For any given initial central bank loan $m$, a household maximizes his total utility by making a goods sale bid in an amount equal to his endowment net of taxes. Given the government strategy, this household must be indifferent between supplying his goods in markets 1,2 or 4 , as they all have the same price, $P$, i.e. $c_{m}^{1}+c_{m}^{2}+c_{m}^{4}=1-T$. He makes a sale bid for all his initial money holdings $m$ to market 3, redeems all his bonds and consumes $c=\frac{m}{P_{3}}+\frac{B}{P}$. With the dollars obtained in exchange for his goods sale bids, i.e. $P\left(c_{m}^{1}+c_{m}^{2}+c_{m}^{4}\right)$, he repays the central bank loan plus interest. Hence, as $P>\widetilde{P}>0$, some households are choosing $m_{c}^{1}>0$ which, as just shown, is suboptimal. In case that $P<\widetilde{P}$, the government sets $P_{4}=\widetilde{P}$. A household maximizes his utility by making a goods sale bid in market 4 for an amount equal to his endowment net of taxes, i.e. $c_{m}^{4}=1-T_{1}$. He makes a sale bid for all his initial money holdings $m$, being indifferent between markets 1 and 3, as the price in both is $P$. He redeems all his bonds and consumes $c=(m+B) / P$. Thus, making a positive goods sale bid in markets 1 or 2 is not optimal and $P<\widetilde{P}$ cannot be an equilibrium either.

\section{References}

[1] BASSETtO, M. (2002). "A Game-Theoretic View of the Fiscal Theory of the Price Level", Econometrica, 70, pp. 2167-2195.

[2] - (2005). "Equilibrium and Government Commitment", Journal of Economic Theory, 124, pp. $79-105$.

[3] - (2007). "Fiscal Theory of the Price Level," in The New Palgrave Dictionary of Economics 2nd Edition, Hampshire, England: Palgrave Macmillan Ltd., forthcoming.

[4] BUITER, W. (2002). "The Fiscal Theory of the Price Level: A Critique", Economic Journal, 112, July, pp. 459-480.

[5] ChRistianO, L. J., and T. J. FITZGERALD (2000). "Understanding the Fiscal Theory of the Price Level", Federal Reserve Bank of Cleveland Economic Review, 36, pp. 2-38.

[6] COCHRAne, J. (2001). "Long-Term Debt and Optimal Policy in the Fiscal Theory of the Price Level", Econometrica, 69, pp. 69-116.

[7] — (2005). "Money as Stock", Journal of Monetary Economics, 52, pp. 501-528.

[8] CUSHING, M. J. (1999). "The Indeterminacy of Prices under Interest Rate Pegging: The non-Ricardian Case", Journal of Monetary Economics, 44, pp. 131-148.

[9] DANIEL, B. C. (2007). "The Fiscal Theory of the Price Level and Initial Government Debt", Review of Economic Dynamics, 10, pp. 193-206.

\footnotetext{
${ }^{20}$ Obviously, if any of the four first equalities in (25) does not hold, then at least one household is not maximizing his utility given the set of constraints. The case in which $P_{2} \neq P$ can be handled following the argument developed below, which is based on the existence of arbitrage opportunities whenever the price in two or more markets differ.
} 
[10] DAVIG, T., and E. LEEPER (2006). "Fluctuating Macro Policies and the Fiscal Theory", NBER Macroeconomics Annual 2006.

[11] DIAMOND, D. W., and R.G. RAJAN (2006). "Money in a Theory of Banking," American Economic Review, 96, pp. 30-53.

[12] DUBEY, P., and J. GEANAKOPLOS (1992). "The Value of Money in a Finite-Horizon Economy: A Role for Banks", in Economic Analysis of Markets and Games, by P. Dasgupta, D. Gale, O. Hart and E. Maskin (Eds.), The MIT Press: Cambridge (Mass.).

[13] — (2006). "Determinacy with Nominal Assets and Outside Money", Economic Theory, 27, pp. $79-106$.

[14] GALE, D. (2005). Liquidity, Interest, and Asset Prices, mimeo, New York University.

[15] KOCHERLAKOTA, N. R., and C. PHELAN (1999). "Explaining the Fiscal Theory of the Price Level", Federal Reserve Bank of Minneapolis Quarterly Review, 23, pp. 14-23.

[16] LEEPER, E. (1991). "Equilibria under Active and Passive Monetary Policies", Journal of Monetary Economics, 27, pp. 129-147.

[17] MCCALLUM, B. T. (2001). "Indeterminacy, Bubbles, and the Fiscal Theory of Price Level Determination", Journal of Monetary Economics, 47, pp. 19-30.

[18] NIEPELT, D. (2004). "The Fiscal Myth of the Price Level", Quarterly Journal of Economics, 119, pp. $277-300$.

[19] OBSTFELD, M., and K. ROGOFF (1983). "Speculative Hyperinflations in Maximizing Models: Can We Rule Them Out?", Journal of Political Economy, 91, pp. 675-687.

[20] SARGENT, T. J., and N. WALLACE (1981). "Some Unpleasant Monetarist Arithmetic", Federal Reserve bank of Minneapolis Quarterly Review, Fall.

[21] SIMS, C. A. (1994). "A Simple Model for Study of the Determination of the Price Level and the Interaction of Monetary and Fiscal Policy", Economic Theory, 43, pp. 381-399.

[22] — (1999). Domestic Currency Denominated Government Debt as Equity in the Primary Surplus, mimeo, Princeton University.

[23] WALLACE, N. (1981). "A Hybrid Fiat-Commodity Monetary System", Journal of Economic Theory, 25, pp. 421-430.

[24] WOODFORD, M. (1994). "Monetary Policy and Price Level Determinacy in a Cash-inAdvance Economy", Economic Theory, 43, pp. 345-380.

[25] - (1995). "Price Level Determinacy without Control of a Monetary Aggregate", CarnegieRochester Conference Series on Public Policy, 43, pp. 1-46.

[26] - (1998). Public Debt and the Price Level, mimeo, Princeton University.

[27] - (2001). "Fiscal Requirements for Price Stability", Journal of Money, Credit, and Banking, 33, pp. 669-728. 


\section{BANCO DE ESPAÑA PUBLICATIONS}

\section{WORKING PAPERS ${ }^{1}$}

0626 CRISTINA BARCELÓ: A Q-model of labour demand.

0627 JOSEP M. VILARRUBIA: Neighborhood effects in economic growth.

0628 NUNO MARTINS AND ERNESTO VILLANUEVA: Does limited access to mortgage debt explain why young adults live with their parents?

0629 LUIS J. ÁLVAREZ AND IGNACIO HERNANDO: Competition and price adjustment in the euro area.

0630 FRANCISCO ALONSO, ROBERTO BLANCO AND GONZALO RUBIO: Option-implied preferences adjustments, density forecasts, and the equity risk premium.

0631 JAVIER ANDRÉS, PABLO BURRIEL AND ÁNGEL ESTRADA: BEMOD: A dsge model for the Spanish economy and the rest of the Euro area.

0632 JAMES COSTAIN AND MARCEL JANSEN: Employment fluctuations with downward wage rigidity: The role of moral hazard.

0633 RUBÉN SEGURA-CAYUELA: Inefficient policies, inefficient institutions and trade.

0634 RICARDO GIMENO AND JUAN M. NAVE: Genetic algorithm estimation of interest rate term structure.

0635 JOSÉ MANUEL CAMPA, JOSÉ M. GONZÁLEZ-MÍNGUEZ AND MARÍA SEBASTIÁ-BARRIEL: Non-linear adjustment of import prices in the European Union.

0636 AITOR ERCE-DOMÍNGUEZ: Using standstills to manage sovereign debt crises.

0637 ANTON NAKOV: Optimal and simple monetary policy rules with zero floor on the nominal interest rate.

0638 JOSÉ MANUEL CAMPA AND ÁNGEL GAVILÁN: Current accounts in the euro area: An intertemporal approach.

0639 FRANCISCO ALONSO, SANTIAGO FORTE AND JOSÉ MANUEL MARQUÉS: Implied default barrier in credit default swap premia. (The Spanish original of this publication has the same number.)

0701 PRAVEEN KUJAL AND JUAN RUIZ: Cost effectiveness of R\&D and strategic trade policy.

0702 MARÍA J. NIETO AND LARRY D. WALL: Preconditions for a successful implementation of supervisors' prompt corrective action: Is there a case for a banking standard in the EU?

0703 PHILIP VERMEULEN, DANIEL DIAS, MAARTEN DOSSCHE, ERWAN GAUTIER, IGNACIO HERNANDO, ROBERTO SABBATINI AND HARALD STAHL: Price setting in the euro area: Some stylised facts from individual producer price data.

0704 ROBERTO BLANCO AND FERNANDO RESTOY: Have real interest rates really fallen that much in Spain?

0705 OLYMPIA BOVER AND JUAN F. JIMENO: House prices and employment reallocation: International evidence.

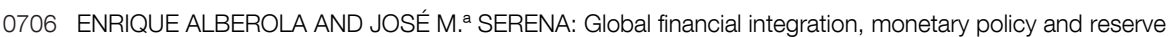
accumulation. Assessing the limits in emerging economies.

0707 ÁNGEL LEÓN, JAVIER MENCÍA AND ENRIQUE SENTANA: Parametric properties of semi-nonparametric distributions, with applications to option valuation.

0708 ENRIQUE ALBEROLA AND DANIEL NAVIA: Equilibrium exchange rates in the new EU members: external imbalances vs. real convergence.

0709 GABRIEL JIMÉNEZ AND JAVIER MENCÍA: Modelling the distribution of credit losses with observable and latent factors.

0710 JAVIER ANDRÉS, RAFAEL DOMÉNECH AND ANTONIO FATÁS: The stabilizing role of government size.

0711 ALFREDO MARTíN-OLIVER, VICENTE SALAS-FUMÁS AND JESÚS SAURINA: Measurement of capital stock and input services of Spanish banks.

0712 JESÚS SAURINA AND CARLOS TRUCHARTE: An assessment of Basel II procyclicality in mortgage portfolios.

0713 JOSÉ MANUEL CAMPA AND IGNACIO HERNANDO: The reaction by industry insiders to M\&As in the European financial industry.

0714 MARIO IZQUIERDO, JUAN F. JIMENO AND JUAN A. ROJAS: On the aggregate effects of immigration in Spain.

0715 FABIO CANOVA AND LUCA SALA: Back to square one: identification issues in DSGE models.

0716 FERNANDO NIETO: The determinants of household credit in Spain.

0717 EVA ORTEGA, PABLO BURRIEL, JOSÉ LUIS FERNÁNDEZ, EVA FERRAZ AND SAMUEL HURTADO: Update of the quarterly model of the Bank of Spain. (The Spanish original of this publication has the same number.)

0718 JAVIER ANDRÉS AND FERNANDO RESTOY: Macroeconomic modelling in EMU: how relevant is the change in regime?

1. Previously published Working Papers are listed in the Banco de España publications catalogue. 
0719 FABIO CANOVA, DAVID LÓPEZ-SALIDO AND CLAUDIO MICHELACCI: The labor market effects of technology shocks.

0720 JUAN M. RUIZ AND JOSEP M. VILARRUBIA: The wise use of dummies in gravity models: Export potentials in the Euromed region.

0721 CLAUDIA CANALS, XAVIER GABAIX, JOSEP M. VILARRUBIA AND DAVID WEINSTEIN: Trade patterns, trade balances and idiosyncratic shocks.

0722 MARTíN VALLCORBA AND JAVIER DELGADO: Determinantes de la morosidad bancaria en una economía dolarizada. El caso uruguayo.

0723 ANTÓN NÁKOV AND ANDREA PESCATORI: Inflation-output gap trade-off with a dominant oil supplier.

0724 JUAN AYUSO, JUAN F. JIMENO AND ERNESTO VILLANUEVA: The effects of the introduction of tax incentives on retirement savings.

0725 DONATO MASCIANDARO, MARÍA J. NIETO AND HENRIEITE PRAST: Financial governance of banking supervision.

0726 LUIS GUTIÉRREZ DE ROZAS: Testing for competition in the Spanish banking industry: The Panzar-Rosse approach revisited.

0727 LUCÍA CUADRO SÁEZ, MARCEL FRATZSCHER AND CHRISTIAN THIMANN: The transmission of emerging market shocks to global equity markets.

0728 AGUSTÍN MARAVALL AND ANA DEL RíO: Temporal aggregation, systematic sampling, and the Hodrick-Prescott filter.

0729 LUIS J. ÁLVAREZ: What do micro price data tell us on the validity of the New Keynesian Phillips Curve?

0730 ALFREDO MARTÍN-OLIVER AND VICENTE SALAS-FUMÁS: How do intangible assets create economic value? An application to banks.

0731 REBECA JIMÉNEZ-RODRÍGUEZ: The industrial impact of oil price shocks: Evidence from the industries of six OECD countries.

0732 PILAR CUADRADO, AITOR LACUESTA, JOSÉ MARÍA MARTÍNEZ AND EDUARDO PÉREZ: El futuro de la tasa de actividad española: un enfoque generacional.

0733 PALOMA ACEVEDO, ENRIQUE ALBEROLA AND CARMEN BROTO: Local debt expansion... vulnerability reduction? An assessment for six crises-prone countries.

0734 PEDRO ALBARRÁN, RAQUEL CARRASCO AND MAITE MARTÍNEZ-GRANADO: Inequality for wage earners and self-employed: Evidence from panel data.

0735 ANTÓN NÁKOV AND ANDREA PESCATORI: Oil and the Great Moderation.

0736 MICHIEL VAN LEUVENSTEIJN, JACOB A. BIKKER, ADRIAN VAN RIXTEL AND CHRISTOFFER KOK-SØRENSEN: A new approach to measuring competition in the loan markets of the euro area.

0737 MARIO GARCÍA-FERREIRA AND ERNESTO VILLANUEVA: Employment risk and household formation: Evidence from differences in firing costs.

0738 LAURA HOSPIDO: Modelling heterogeneity and dynamics in the volatility of individual wages.

0739 PALOMA LÓPEZ-GARCÍA, SERGIO PUENTE AND ÁNGEL LUIS GÓMEZ: Firm productivity dynamics in Spain.

0740 ALFREDO MARTÍN-OLIVER AND VICENTE SALAS-FUMÁS: The output and profit contribution of information technology and advertising investments in banks.

0741 ÓSCAR ARCE: Price determinacy under non-Ricardian fiscal strategies.

\begin{tabular}{|r|c|}
\hline & Unidad de Publicaciones \\
BANCODEESPAÑ & Alcalá, 522; 28027 Madrid \\
Eurosistema & Telephone +34 91 338 6363. Fax +34913386488 \\
& e-mail: publicaciones@bde.es \\
www.bde.es
\end{tabular}

